\title{
Improving Democracy Resilience by Contexts: Digitalization and Participation in Indonesia
}

\author{
George Towar Ikbal Tawakkal \\ \{george.ikbal@ub.ac.id\} \\ Universitas Brawijaya, Indonesia
}

\begin{abstract}
In the last twenty years, the Indonesian government and democracy activists have adopted various democratic values in government practices, including the use of digital technology in strengthening democracy resilience, by increasing public participation in government management. From the central government to local governments, they have built applications to make it easier for people to interact with the government. This article will discuss the arguments of scholars when they evaluated the use of digital technology in Indonesia, the level of democracy, the sources, and what scholars need to do. This article was written by discussing various literature from recent researches and using critical analysis to build a new perspective. The results show that many scholars claim that democracy in Indonesia is not working as they hope, including the weak of accessing digital technology in participation. They put Indonesia in a low level of democracy rank. So, is digital technology suitable for Indonesian democracy? The low level of democracy and the low benefits from adopting certain democratic concepts might be caused by mistakes in how they view Indonesia. They use variables and concepts which came from other countries or other societies. This article offers a contextual perspective on how we view Indonesian democracy. We call it as MacGyvering Democratization. A concept for viewing context. From the perspective, we can answer the question, is digital technology suitable for Indonesian democracy?. That will help more for improving democracy in Indonesia. That is fairer.
\end{abstract}

Keywords: Democracy, Resilience, Digital, MacGyvering, Context.

\section{Introduction}

Citizen participation is generally believed to be an important element of democracy. However, the question about how they should do it has been debated for thousands of years. There are two ways citizens can participate, direct and indirect democracy. But it must be emphasized that there are various practices in these categories. Direct democracy provides an opportunity for citizens to directly determine the form of laws, policies and public services, which they will directly feel in their daily lives, without involving intermediaries. In other ways, democracy does not directly involve intermediaries, who we know as representatives, to act on behalf of citizens. Direct democracy is often seen as a form of 'pure' democracy. Today many governments provide instruments to enhance direct democracy, to improve the quality of decision making to better suit citizens' needs. The practice of direct democracy was first carried out in Athens in the 4th and 5th centuries BC. However, the democracy that was practiced in Athens is different from the democracy that we know today. There is only one similarity between democracy in Athens and democracy today, an idea that power must be 
exercised by those who are targeted by that power, or at least accountable to these people [1]. This value, accountability, is a value that is applied to indirect or representative democracy. Citizens elect or appoint representatives to act on their behalf, if the performance fails then he will not be elected or appointed for the next period. This is the form of accountability. Indeed, accountability does not occur shortly after he fails, and it is necessary to wait until the period is over. But that is precisely the advantage of representative democracy, and the solution to a complex social and economic system [2]. However, debates about how citizens control decision making still occur.

In today's technological era, many countries utilize information technology to increase efficiency and effectiveness, as well as provide opportunities for citizens to participate and be involved online [3]. The use of information technology in the public sector has a long history since the development of computerization in the 1970s to the 1990s. This development was responded by the government to obtain efficiency through simplification and automation of service delivery [4]. In line with that, e-government is starting to become an important value in the political system. Even the government began to issue regulations that encourage the use of technology. For example in the United States, the federal government passed a law, the Clinger-Cohen Act of 1996 to encourage the modernization of the management in the federal government into electronic systems [5]. Furthermore, the use of technology began to be directed towards democratization. So that citizens have more opportunities to be involved in governance. The internet and computers help governments to communicate their policies directly to citizens. Confidence in the use of technology has strengthened with the increase in social and cellular media users. Citizens increasingly have the opportunity to provide policy feedback quickly and easily.

Many scholars mentioned that local governments in the United States have led to the implementation of e-government [6]. Many scholars have also developed the concept of egovernment growth in local government, from providing one-way information to two-way interactions [7]. A survey conducted by Norris and Reddick (2013) shows that more than 90 percent of local governments in the United States provide important information online, in addition to online transaction services [8]. Manoharan (2013) found that more than 75 percent of counties in the US had developed official Web sites, and the others were developing [7].

Transforming governance is not only in developed countries but also in developing countries, such as in Indonesia. The development of technology and awareness to carry out governance reforms has encouraged the government to issue regulations on e-government. The government issued Presidential Instruction No. 3 of 2003 on national policy and strategy development of e-government, which forms the legal basis for implementing e-government for the establishment of a clean, transparent and able government to effectively respond to demands for change. With e-government, the government is expected to be able to provide public services that are effective, efficient, and interactively accessible to all citizens. By egovernment, the government gives an easy channel for participation (Huda 2018) [9].

The instruction was responded to by the development of e-government at various levels of government. For example, each government agency in Indonesia already has an official website, which aims to publicize all the activities and policies of that agency. At every level of government, e-procurement or LPSE (electronic procurement service) applications have also been provided, to maintain transparency of the government job auction process so that citizens can participate in management and supervision. Also, several governments have provided interactive channels that citizens can use to complain or give advice to the government. At the national level, the government issues LAPOR [10], an electronic service for citizens complaining about public services. This service manages complaints about all ministry 
agencies effectively and integrated. Even so, the village ministry also has e-complaints, an electronic complaint service. At the local level, local governments also issue electronic services for participating citizens. For example, the Binjai city government has built EMasyarakat [11], an android application, as an online channel for citizens to submit complaints or reports. The Semarang city government issued the Lapor Hendi service, which utilizes social media, one of them is an android application [12], to interact with the citizens of Semarang City. These examples are only a small part of electronic participation services in Indonesia.

What does Indonesia get from massive e-government development? Does it contribute to participation? What must we do as scholars? This paper will discuss the arguments of scholars when they evaluated the use of digital technology in Indonesia, the level of democracy, the sources, and what we need to do in the next.

\section{Research Methods}

This article will discuss various literature and report from recent researches and using critical analysis to build a new perspective. For building the argument, this paper consists of three sessions. First, I will present recent research and reports that various institutions and scholars have conducted, for identifying the evaluation of the e-government, especially eparticipation. Second, I will present arguments about problems in the e-government implementation. Third, I will analyze their perspectives. Fourth, I will conclude by proposing a new perspective.

\section{Results and Discussion}

\subsection{Indices and the Fluctuations}

The effects of massive e-government development in Indonesia, especially eparticipation, can be seen through the UNDP report which presents the e-government index [13]. It consists of the e-government development index and the e-participation index. The EGovernment Development Index (EGDI) is a composite measure of three important dimensions of e-government, namely: provision of online services, telecommunication connectivity, and human capacity. The e-participation index (EPI) focuses on the use of online services to facilitate information by governments to citizens ("e-information sharing"), interaction with stakeholders ("e-consultation"), and engagement in decision-making processes ("e-decision making"). We will compare both for understanding the patterns.

With index value between $0-1$, Indonesia has 0.4224 in the first year The UNDP measured the e-government index, 2003. This value decreased in 2004, to 0.3909, then in 2005 to 0.3819 . The value increased in 2008 to 0.4107 . But this value decreased in 2010 , to 0.4026 . There was a significant increase in 2012 , to 0.4949 , then that value decreased in 2014 to 0.4487 , then in 2016 to 0.4478 . In 2018, the EGDI value increased to 0.5258 . These values indicate that e-government development in Indonesia has fluctuated. However, compared to the first year, e-government development in Indonesia increased significantly. But the recent value is still medium. In Southeast Asia countries, the value is only higher than Bangladesh, Timor-Leste, Cambodia, and Myanmar. 
For e-participation, in 2003 Indonesia received 0.2586 , and increased slightly in 2004 to 0.2623 , in 2005 to 0.2857 . In 2008 , that number decreased significantly to 0.0455 . But then in 2010 it increased to 0.1286 and increased significantly in 2012 to 0.2105 . The increase continues to occur in 2014 to 0.2941 , in 2016 to 0.3729 . In 2018 the increase will be very significant to 0.6180 . It looks Indonesia got good achievements in using technology for participation. If we compare with the EGDI, we will find that the values are not linear. Sometimes, with higher value in the EGDI, Indonesia has a higher value in the EPI (see 2010 to 2012, 2016 to 2018). Sometimes, with higher value in the EGDI, Indonesia has lower value in the EPI (see 2005 to 2008). Sometimes, with a lower value in the EGDI, Indonesia has a higher value in the EPI (see 2003 to 2004, 2004 to 2005, 2008 to 2010, 2012 to 2014, and 2014 to 2016). The last is most cases. No cases for lower value in the EGDI result in a lower value in the EPI. This fluctuation is not Indonesia only. In Southeast Asia countries, we have Malaysia, Singapore, Bangladesh, and Timor Leste.

Comparing with other Southeast Asia countries is interested. From the UNDP report, we found various evidence for the most pattern in every index period by comparing it with the previous year. In Indonesia, comparing with the previous year, decreasing value in the EGDI has increasing value in the EPI. In Malaysia, comparing with the previous year, increasing value in the EGDI has increasing value in the EPI. But, they have four non-linear of eight cases. In Singapore, comparing with the previous year, increasing value in the EGDI has increasing value in the EPI. But, they have three non-linear of eight cases. Timor Leste, comparing with the previous year, increasing value in the EGDI has decreasing value in the EPI. What the meaning? Developing e-government is not equal to e-participation achievement.

The other result can be driven by comparing the countries by considering the EGDI achievement and the EPI achievement. Bangladesh (0.4862) has lower achievement than Indonesia (0.5258) in the EGDI, but Bangladesh (0.8034) has far higher achievement than Indonesia (0.6180) in the EPI. Philippine (0.6512) has lower achievement in the EGDI than Malaysia (0.7174), but Philippine (0.9362) has higher achievement than Malaysia (0.8876) in the EPI. Not only have both cases, but many countries also had such cases. What the meaning? Developing e-government has various results in e-participation, in each country.

Another index is presented by The Economist Intelligence Unit (The EIU) [14]. They released the democracy index around the world, including participation. With index value between 1-10, Indonesian participation started at 5.56 in the first-year period, 2010. Indonesia kept its value in 2011, and increase to 6.11 in 2012. But the value has decreased in 2013 to 5.00. The value increases significantly in 2014 to 6.67 , then stagnant at the point until 2018 . Comparing with the E-participation by UNDP, it looks that the increasing e-participation does not influence participation. Referring to Gronlun's study when he tried to connect between egovernment and real government in the authoritarian regime, the e-participation failed to explain the real participation. The relation between the index and democracy and participation does not exist.

\subsection{Causing the Ineffective E-Participation}

Many scholars tried to explain why e-government cannot increase participation. For example, Kurniawan. He explained the implementation of e-musrenbang by the Surabaya City Government and DKI Jakarta Provincial Government. e-musrenbang is a musrenbang by electronic technology. Musrenbang refers to development planning forums that involve stakeholders, one of them is the community[15]. 
Kurniawan said that the number of proposals submitted through e-musrenbang had decreased. More people submit proposals manually, through a consultation process in lower level government administration, such as RW, through representation by community leaders and not the community directly. He explained the weakness of e-readiness as the cause of the ineffectiveness of e-musrenbang. The low ability of the community to be actively involved in e-musrenbang, is one of the reasons why people do not utilize e-musrenbang properly.

Napitupulu et al also showed how e-government failed to increase public participation. The development of E-Government is merely pursuing the application of technology, without involving the community in the development process. As a result, the implementation of egovernment cannot adjust to the needs of the community. Although citizens' interests and perceptions about e-participation are very high, the level of public participation is still low [16].

\subsection{The Urgency of a New Perspective}

The indexes and the research showed that digitalization is not linear with participation. So, should we consider digitalization to make participation more effective? Should we think that digitalization is an urgent channel? Should we talk about technology for democracy, especially participation? if we choose to impose digital technology, it will produce more negative evaluations. While scholars blame the community for the failure of technology in participation. Why don't we develop an acceptable channel for participation? How to identify the acceptable channel?

The studies above can imply that they started the way of thinking by setting their minds that the application of technology is a measure of democracy. So they evaluate and address negative terms for a country's democracy. While some scholars blame the community as a reason for the failure of the application of technology. This way of thinking is not only normative but also strange when scientists have the responsibility for social development.

Their way of thinking can be described analogously as follows. Someone is holding a saw, to cut a cake. The first scholar came to say that the saw would destroy the cake. The second scholar recommended that the person not use a saw. The third scholar even tried to convince that the cake was wrong. The person still uses the saw to cut the cake. Although crushed every cut, but the person still enjoys the cake. If so, what are the benefits of what these scholars say? First graduates, like journalists, only present information without a solution. The second graduate seemed to intervene but without a solution. The third expert, blaming aggressively. The scholars lacked the benefit of the neatness of the cake cuttings with saws. Then what should be done by scholars? Find solutions to what that person has, namely a saw so that the cake is neatly cut. Scholars need to understand saws. Are there opportunities to cut neatly? The saw has two sides, jagged down, and flat on the top. The flat part is strong and quite smooth. If the saw is turned over and used to cut a cake, you will get a neat piece of cake. This is how scientists should become MacGyver.

Scientists who uphold the value of democracy must have the courage to reverse their paradigm of voice brokers. Of course, without forgetting the basic idea of democracy. With the analog above, scientists must dare to explore the practices that already exist in society, so they can map the opportunities that exist to increase participation. The flow of thinking so, what is to be achieved, what is in the community, then identify opportunities, find solutions. That way, scientists will be fairer about the situation, where contextual democratization will be found, which I call MacGyvering democratization, where democratization is carried out by exploring the potentials in society, utilizing existing daily practices to improve democracy. 
My doctoral dissertation found the potential. Indonesian has presented a long-standing practice in elections, namely intermediary institutions. Intermediary institutions refer to institutions that connect candidates and voters. Most scholars see intermediary institutions as a negative element for democracy and call them voice brokers [17]. Their studies always use a transactional framework to explain things about the institution. To find a positive value from the existence of these institutions, my dissertation uses a different perspective, namely MacGyvering democratization. I tested the institution's social capital to see if it could characterize a civil society. As a result, several types of intermediary institutions have the potential to become a citizen participation movement after the election. The networks, trusts, values, norms, and resources of certain kinds of intermediary institutions have the potential to be an effective channel for citizen participation [18].

\section{Conclusion}

Digital technology has developed rapidly. Governments in the world react to this by digitizing in the public sector, specifically participation. In Indonesia, the development of eparticipation was carried out on a massive scale, from the national to the local level. However, evaluations conducted by various international institutions and scholars show that eparticipation development does not result in a significant increase in participation. They even embed negative terms to describe the situation. While scholars blame the community. There are two important lessons from them. First, e-participation is not effective in Indonesia. Second, scholars always blame the community. If so, what contributions can scholars present? I propose the concept of MacGyvering democratization, to change the way of thinking of scholars. Scholars need to look at the context of Indonesian society. When Indonesian society is not compatible with e-participation, scholars should be able to find compatible channels. That will make democracy resilience in Indonesia. Referring to the practices that already exist in the community, my dissertation found the potential of an intermediary institution in the election to become a channel for citizen participation after the election.

\section{References}

[1] A. Cole, "Decentralization in France: Central steering, capacity building and identity construction," French Polit., vol. 4, no. 1, pp. 31-57, 2006.

[2] D. Held, Models Of Democracy. Cambridge: Polity Press, 1996.

[3] A. P. Manoharan and M. Holzer, Active Citizen Participation In E-Government: A Global Perspective. USA: IGI Global, 2012.

[4] M. H. Sprecher, "Racing to e-government: Using the Internet for citizen service delivery," Gov. Financ. Rev., vol. 16, no. 5, p. 21, 2000.

[5] A. P. Manoharan and A. Ingrams, "Conceptualizing e-government from local government perspectives," State Local Gov. Rev., vol. 50, no. 1, pp. 56-66, 2018.

[6] J. E. Benton, "An assessment of research on American counties," Public Adm. Rev., vol. 65, no. 4, pp. 462-474, 2005.

[7] A. Manoharan, "A three dimensional assessment of US county e-government," State Local Gov. Rev., vol. 45, no. 3, pp. 153-162, 2013.

[8] D. F. Norris and C. G. Reddick, "Local e-government in the United States: Transformation or incremental change?," Public Adm. Rev., vol. 73, no. 1, pp. 165-175, 2013.

[9] M. Huda and N. S. Yunas, "The Development Of E-Government System In Indonesia," J. Bina Praja, vol. 8, no. 1, pp. 97-108, 2016. 
[10] "No Title." [Online]. Available: lapor.go.id.

[11] "No Title." [Online]. Available: https://play.google.com/store/apps/details?id=smartcity.aplikasi\&hl=en.

[12] "No Title." [Online]. $\quad$ Available: https://play.google.com/store/apps/details?id=com.semarang.laporhendi\&hl=en.

[13] "No Title." [Online]. Available: https://publicadministration.un.org/egovkb/en-us/reports/un-egovernment-survey-2018.

[14] "No Title." [Online]. Available: http://www.eiu.com/topic/democracy-index.

[15] T. Kurniawan, "E-Musrenbang As A Means In Increasing Community Participation In Development Planning In Indonesia: Its Challenges And Obstacles," in 2018 Annual Conference of Asian Association for Public Administration:" Reinventing Public Administration in a Globalized World: A Non-Western Perspective"(AAPA 2018), 2018.

[16] D. Napitupulu and K. Adiyarta, "Public Participation Readiness Toward E-Gov 2.0: Lessons from Two Countries," in Proceedings of the 12th International Conference on Theory and Practice of Electronic Governance, 2019, pp. 240-243.

[17] E. Aspinall, Politik uang di Indonesia: Patronase dan klientelisme pada pemilu legislatif 2014. Research Centre for Politics and Government, Department of Politics ..., 2015.

[18] G. T. I. Tawakkal, Gapit: Bekerjanya Jejaring Sosial Di Pilkada Demak 2015, Research Doctoral Dissertation, Program Doktor Ilmu Sosial, Universitas Diponegoro, Semarang, Indonesia. 2017. 